\title{
Pengaruh Kualitas Pelayanan Terhadap Kepuasan Pelanggan Pada PT. PLN (Persero) Rayon Jawi Pontianak
}

\author{
ANITALIBRIANTY \\ RUDI TRIADI YULIARTO \\ STIE Boedi Oetomo \\ Jl. Ampera, No. GG 1-2 Kota Baru, Pontianak \\ email : syifapga@gmail.com
}

Diterima 9 September 2018; disetujui 15 November 2018;

\begin{abstract}
The purpose of this research is to examine the influence of obedience and compensation to performance at the office of the regional secretariat of Pontianak. The sample was 70 employees. The data was collected through questionnaire and analyzed with multiple linier regression. The result showed that obedience has a positive significant relationship to performance, while compensation didn't have relationship to performance at the office of the regional secretariat of Pontianak.
\end{abstract}

Keywords: dividend policy, profitability, ownership structure, growth, and business effectiveness.

\section{PENDAHULUAN}

Latar Belakang. Era globalisasi sekarang ini, menuntut Badan Usaha Milik Negara (BUMN) untuk meningkatkan pelayanan secara profesional sesuai dengan bidangnya masing-masing. Perubahan teknologi dan arus informasi yang sangat cepat telah mendorong perusahaan untuk menghasilkan produk atau layanan yang dapat memenuhi kebutuhan dan keinginan konsumen, sehingga konsumen merasa puas dengan apa yang telah mereka dapatkan dari perusahaan. Banyak cara yang dapat dilakukan perusahaan dalam memenuhi kebutuhan dan keinginan konsumen, salah satunya yaitu dengan memberikan kesan/citra yang baik dalam hal produk maupun pelayanan kepada konsumen.

PT. PLN (Persero) merupakan salah satu Perusahaan Milik Negara yang memberikan pelayanan kepada calon pelanggan dan masyarakat dalam penyediaan jasa yang berhubungan dengan penjualan tenaga listrik satu-satunya di Indonesia. Peningkatan kebutuhan listrik melonjak dengan tinggi dan cepat, khususnya kebutuhan bagi industri dan diiringi pula dengan standar tingkat kepuasan masyarakat menjadi lebih tinggi lagi sebagai akibat dari meningkatnya pendapatan masyarakat yang maju dan modern. Dalam melakukan kegiatannya, PT. PLN (Persero) menyediakan bagian pelayanan pelanggan yang tugasnya memberikan pelayanan yang dibutuhkan oleh setiap pelanggan.

Sejalan dengan hal di atas, PT. PLN (Persero) berupaya untuk berperan sebagai (1) pendorong, penggerak dan penunjang pembangunan nasional; (2) sarana peningkatan produktivitas dan efisiensi; (3) penunjang lancarnya kegiatan perekonomian dan pemerintahan. Kebutuhan akan jasa listrik di Kalimantan Barat daritahun ke tahun menunjukkan adanya peningkatan. Peningkatan akan dibutuhkannya jasa listrik ini merupakan dampak yang positif untuk menunjang tersalurnya potensi yang dimiliki PT. PLN (Persero). Bagi PT. PLN (Persero) memberikan pelayanan terbaik untuk pelanggan menjadi tolak ukur keberhasilan sebuah perusahaan. Perusahaan yang berhasil memasarkan 
produk kepada konsumen dengan pelayanan yang memuaskan mendapatkan brand yang baik dimata pelanggan. Menurut Zeithaml dan Bitner kualitas layanan adalah ketidak sesuaian antara harapan atau keinginan konsumen dengan persepsi konsumen. Dimensi kualitas jasa menurut Parasuraman, Zeithaml, dan Berry terdapat lima unsur yang menentukan kualitas jasa, yaitu: "tangible, responsiveness, reability, assurance, dan empathy". Assurance atau jaminan, yaitu dimensi yang berhubungan dengan kemempuan perusahaan dan prilaku front-line staf dalam menanamkan rasa percaya dan keyakinan kepada para pelanggannya.

Perusahaan akan berhasil memperoleh pelanggan dalam jumlah yang banyak apabila dinilai dapat memberikan kepuasan bagi konsumen. Konsumen yang merasa puas dan jika konsumen setia maka akan merekomendasikan dari mulut ke mulut. Berdasarkan uraian diatas penulis tertarik untuk membuat penelitian berjudul "Pengaruh Kualitas Pelayanan Terhadap Kepuasan Pelanggan Pada PT. PLN (persero) Rayon Jawi Pontianak

Tujuan Penelitian. Berdasarkan latar belakang tersebut, tujuan dari penelitian ini adalah menganalisis pengaruh kualitas pelayanan jasa yang meliputi tangible, realibility, responsiveness, assurance, dan empathy terhadap kepuasan pelanggan PT. PLN (Persero) Rayon Jawi Kota Pontianak.

\section{TINJAUAN TEORETIS}

Kualitas Pelayanan Publik. Menurut Ratminto dan Winarsih (2007), pelayan publik atau pelayanan umum dapat didefinisikan sebagai segala bentuk jasa pelayanan baik dalam bentuk barang publik maupun jasa publik yang pada prinsipnya menjadi tanggung jawab dan dilaksanakan oleh Instansi Pemerintah di Pusat, di daerah, dan lingkungan Badang Usaha Milik Negara/Daerah, dalam rangka upaya pemenuhan kebutuhan masyarakat maupun dalam rangka pelasanaan ketentuan peraturan perundang-undangan. Sianipar (1999) menjelaskan bahwa "pelayanan publik dapat dinyatakan sebagai segala sesuatu bentuk pelayanan sektor publik yang dilaksanakan aparatur pemerintah dalam bentuk barang dan jasa, yang sesuai dengan kebutuhan masyarakat dan ketentuan peraturan perundang-undangan yang berlaku". Sejalan dengan pendapat di atas maka Senge (1994) mengatakan "public service generally means services rendered by the public sectorthe state or government".

Goetsh dan Davis (dalam Tjiptono Fandy, 2003), kualitas merupakan suatu kondisi dinamis yang berhubungan dengan produk, jasa, manusia, proses, dan lingkungan yang memenuhi atau melebihi harapan. Kualitas atau mutu dalamindustri jasa pelayanan adalah suatu penyajian produk atau jasa sesuai ukuran yang berlaku di tempat produk tersebut diadakan dan penyampaiannya setidaknya sama dengan yang diinginkan dan diharapkan oleh konsumen (Endar Sugiarto, 1999).

Parasuraman et al, 1990 (dalam Kotler, 2007) menyimpulkan bahwa ada lima dimensi ServQual (Service Quality) yang dipakai untuk mengukur kualitas pelayanan,yaitu:

1 Tangibles atau bukti fisik yaitu kemampuan suatu perusahaan dalam menunjukkaneksistensinya kepada pihak eksternal. Penampilan dan kemampuan sarana dan prasarana fisik perusahaan dan keadaanlingkungan sekitarnya adalah bukti nyata dari pelayanan yang diberikanoleh pemberi jasa.

2 Reliability atau keandalan yaitu kemampuan perusahaan untuk memberikan pelayanan sesuai yang dijanjikan secara akurat dan terpercaya.

3 Responsiveness atau ketanggapan yaitu suatu kemauan untuk membantu dan memberikan pelayanan yang cepat (responsif) dan tepat kepada pelanggan, dengan penyampaian informasi yang jelas.

4 Assurance atau jaminan dan kepastian yaitu pengetahuan, kesopansantunan, dan kemampuan para pegawai perusahaan untuk menumbuhkan rasa percaya para pelanggan kepada perusahaan.

5 Emphaty yaitu memberikan perhatian yang tulus dan bersifat individual atau pribadi yang diberikan kepada para pelanggan dengan berupaya memahami keinginan konsumen.

Kotler dan Keller (2009) mengungkapkan kepuasan adalah perasaan senang atau kecewa seseorang yang berasal dari perbandingan antara kesannya terhadap kinerja (atau hasil) suatu produk dan harapan harapannya. Lovelock dan Wright 
(2007) menyatakan bahwa, kepuasan adalah keadaan emosional, reaksi pasca pembelian mereka, dapat berupa kemarahan, ketidakpuasan, kejengkelan, netralitas, kegembiraan dan kesenangan. Kepuasan dipengaruhi oleh perbandingan layanan yang dipahami dengan pelayanan yang diharapkan, dan sebagai reaksi emosional jangka pendek pelanggan terhadap kinerja pelayanan tertentu.

Hipotesis. Berdasarkan tinjauan teoretis dan penelitian terdahulu, maka hipotesis yang diajukan dalam penelitian ini adalah :

H1 : Tangibles berpengaruh positif terhadap kepuasan pelanggan pada PT. PLN (Persero) Rayon Jawi Kota Pontianak

H2 : Reliability berpengaruh positif terhadap kepuasan pelanggan pada PT. PLN (Persero) Rayon Jawi Kota Pontianak

H3 : Responsiveness berpengaruh positif terhadap kepuasan pelanggan pada PT. PLN (Persero) Rayon Jawi Kota Pontianak

H4 : Assurance berpengaruh positif terhadap kepuasan pelanggan pada PT. PLN (Persero) Rayon Jawi Kota Pontianak

H5 : Emphaty berpengaruh positif terhadap kepuasan pelanggan pada PT. PLN (Persero) Rayon Jawi Kota Pontianak

Jenis Penelitian. Jenis penelitian ini adalah penelitian eksplanatif yaitu menjelaskan hubungan sebab akibat dari sejumlah variabel yang diteliti yaitu kualitas pelayanan dengan kepuasan pelanggan. Penelitian ini dilakukan di wilayah kota Pontianak.

Populasi dan Sampel. Populasi adalah sekelompok orang atau kejadian, atau segala sesuatu yang mempeunyai karakteristik tertentu. (Indriantoro, 2002). Populasi dalam penelitian ini yaitu seluruh pelanggan PT. PLN (Persero) Rayon Jawi kecamatan Pontianak Kota, Pontianak selatan dan sampel di penelitian ini sebanyak 100 pelanggan di wilayah Kota Pontianak.

Variabel Penelitian. Variabel bebas di penelitian ini yaitu kualitas pelayanan yang terdiri dari tangible, reability, responsivness, assurance dan emphaty sedangkan variabel terikat yaitu kepuasan pelanggan. Untuk mendapatkan data di penelitian ini menggunakan kuesioner, adapun yang mengisi kuesioner pada penelitian ini adalah seluruh pelanggan PT. PLN (Persero) Rayon Jawi kecamatan Pontianak Kota, Pontianak selatan dan Pontianak Tenggara sebanyak 100 pelanggan di wilayah Kota Pontianak.

Jenis Data. Data yang digunakan dalam penelitian ini adalah data primer. Data dalam penelitian ini bersumber dari rekapitulasi jawaban kuesioner yang dibagikan kepada responden.

Definisi Operasional Variabel. Definisi operasional variabel dalam penelitian ini dapat dilihat pada tabel 1 .

Jenis Data. Data yang digunakan dalam penelitian ini adalah data primer. Data dalam

\section{Gambar 1}

Kerangka Penelitian Pengaruh Kualitas Pelayanan Terhadap Kepuasan Pelanggan Pada PT. PLN (Persero) Rayon Jawi Pontianak

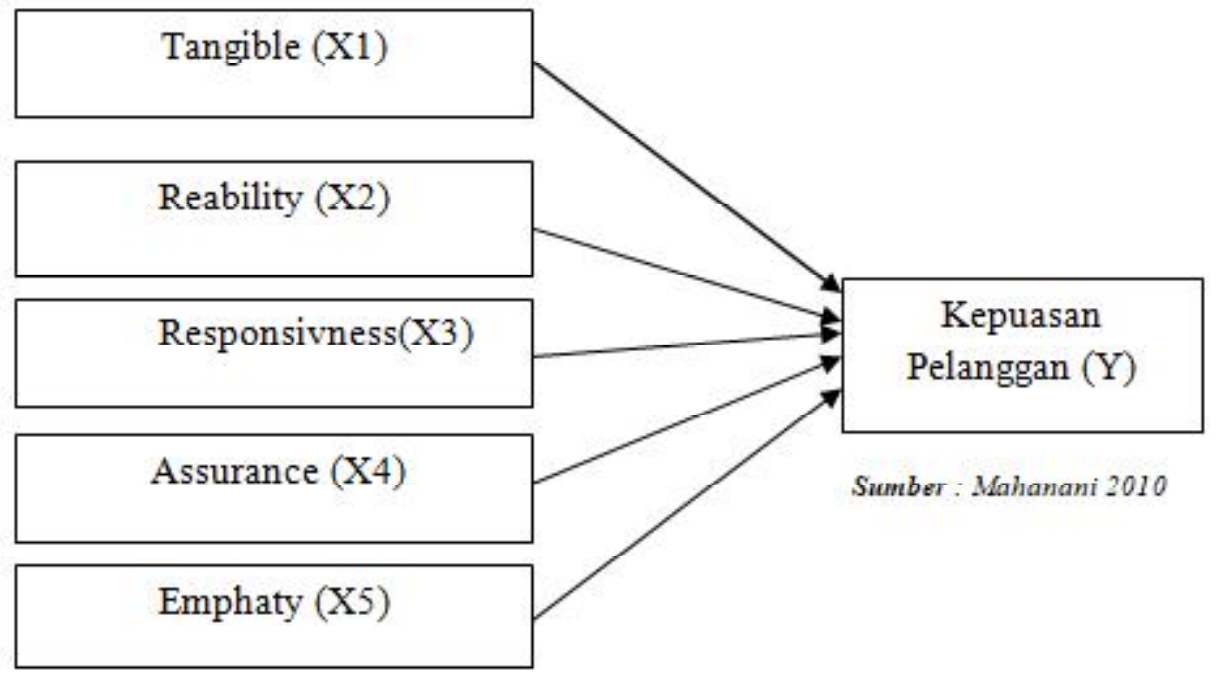


penelitian ini bersumber dari rekapitulasi jawaban kuesioner yang dibagikan kepada responden.

Analisis Data. Dalam penelitian ini data yang diperoleh akan dianalisis menggunakan teknik analisis regresi linier berganda. Persamaan regresi yang digunakan adalah sebagai berikut:

\section{$Y=a+b 1 X 1+b 2 X 2+b 3 X 3+b 4 X 4+b 5 X 5$}

Dimana:

$\begin{array}{ll}\mathrm{Y} & : \text { kepuasan pelanggan } \\ \mathrm{a} & : \text { konstanta } \\ \mathrm{b} & : \text { koefisien regresi } \\ \mathrm{X} 1 & : \text { reliability } \\ \mathrm{X} 2 & : \text { assurance } \\ \mathrm{X} 3 & : \text { tangibles } \\ \mathrm{X} 4 & \text { : empathy } \\ \mathrm{X} 5 & \text { : responsivness }\end{array}$

\section{HASIL DAN PEMBAHASAN}

Statistik Deskriptif. Dari 100 orang responden yang dijadikan sampel penelitian, berdasarkan jenis kelamin responden ternyata didominasi oleh pelanggan yang berjenis kelamin Laki-laki sebanyak 55 orang dengan persentase $55 \%$ dan sisanya adalah responden Perempuan sebanyak 45 orang atau $45 \%$. Berdasarkan pendidikan terakhir yang dimiliki responden, dapat dilihat bahwa sebagian besar responden, 29 atau $29 \%$ diantaranya tamatan SMA, 29 orang atau $29 \%$ sarjana, 25 orang atau $25 \%$ pascasarjana, 10 orang atau $10 \%$ SMP, dan tamatan SD 4 orang atau 4\%. Berdasarkan profesi atau pekerjaan diketahui karakteristik responden yang paling dominan yaitu pegawai atau karyawan sebanyak 42 orang atau $42 \%$, diikuti wiraswasta sebanyak 22 orang atau $22 \%$, selanjutnya lain-lain 22 orang atau $22 \%$ dan terakhir pelajar atau mahasiswa sebanyak 14 orang atau 14\%. Berdasarkan frekuensi pemakaian listrik diketahui karakteristik responden berdasarkan frekuensi pemakaian listrik perbulan, Rp. $100.000-\mathrm{Rp}$. 150.000 sebanyak 35 orang atau $35 \%$, Rp. 50.000- Rp. 100.000 sebanyak 35 orang atau

Tabel 1

Operasional Variabel

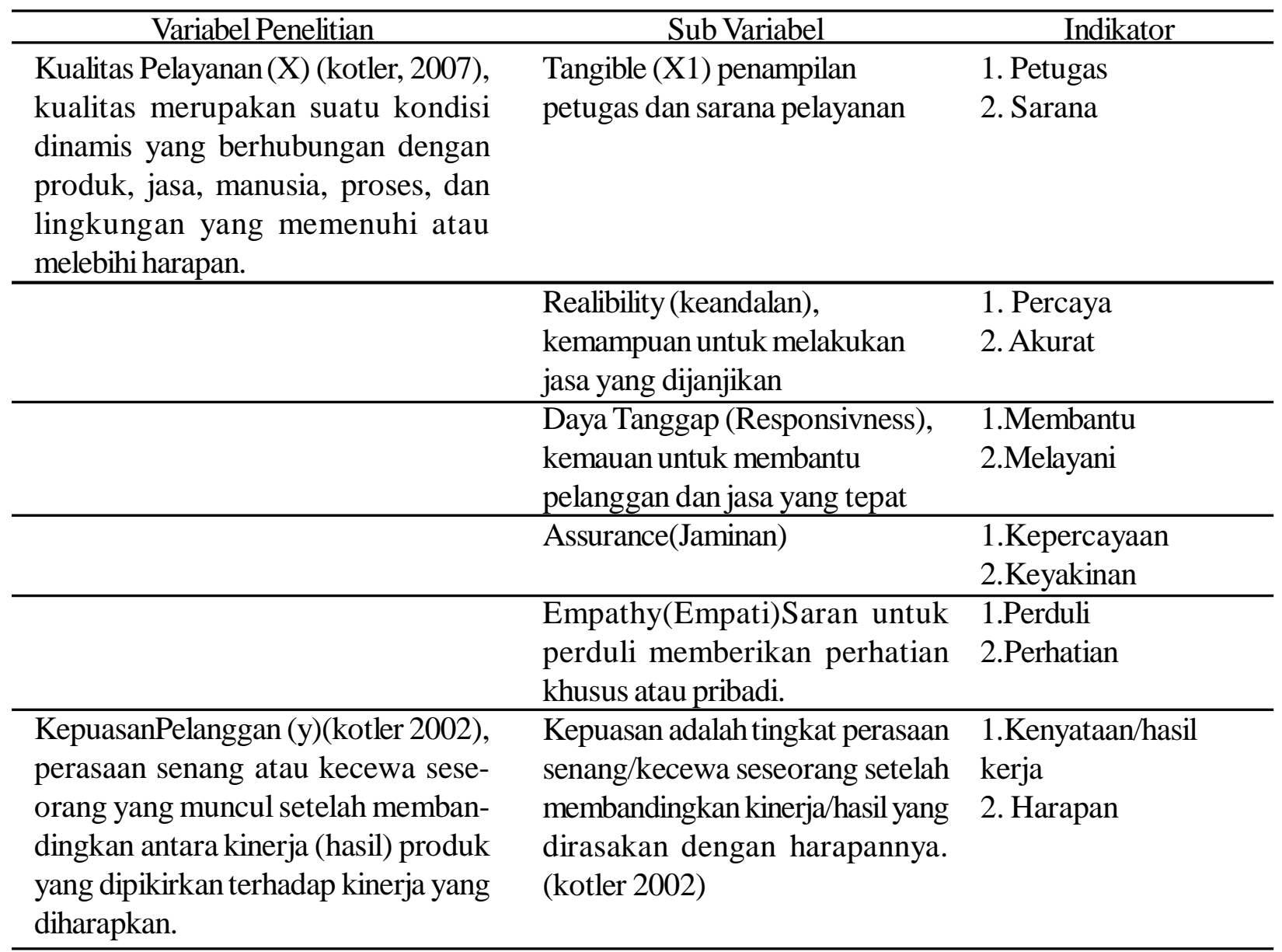


$35 \%,>$ Rp. 150.000 sebanyak 58 orang atau 58\%, dan $<$ Rp.50.000 sebanyak 4 orang atau $4 \%$. Berdasarkan frekuensi pemadaman listrik diketahui karakteristik responden berdasarkan frekuensi pemadaman listrik perbulan, 1 kali sebanyak 18 orang atau $18 \%, 4$ kali sebanyak 13 orang atau 13\%, 2 kali sebanyak 33 orang atau 33\%, dan 3 kali sebanyak 17 orang atau $17 \%$.

Uji Validitas dan Reliabilitas. Dari hasil uji validitas, semua item pertanyaan memiliki nilai korelasi positif dan lebih besar dari 0,6. Hal ini berarti bahwa semua instrumen dalam penelitian ini adalah valid. Begitu pula, hasil uji reliabilitas menunjukkan semua variabel memiliki nilai koefisien Alpha Chronbach lebih besar dari 0,6, yang artinya bahwa seluruh instrumen yang digunakan dalam penelitian ini adalah reliabel.

Uji Asumsi Klasik. Sebelum dilakukan uji regresi linear berganda maka dilakukan uji asumsi klasik, dari hasil uji multikolerianitas menunjukkan bahwa tidak ada nilai VIF yang lebih dari 10 sehingga dapat dikatakan bahwa tidak ada korelasi antara variabel bebas. Selanjutnya nilai signifikansi tiap variabel terhadap absolute residual lebih dari 0,05 , artinya persamaan regresi mengalami homokedastisitas (tidak mengandung Heterokedastisitas) dan untuk uji normalitas data penelitian ini berdistribusi normal, dikarenakan nilai á lebih besar dari 0,05 .

Analisis Regresi Berganda. Analisis regresi berganda dilakukan meliputi variabel bebas tangible $\left(\mathrm{X}_{1}\right)$, faktor realibility $\left(\mathrm{X}_{2}\right)$, faktor respon- siveness $\left(\mathrm{X}_{3}\right)$, faktor assurance $\left(\mathrm{X}_{4}\right)$ dan faktor emphaty $\left(\mathrm{X}_{5}\right)$ terhadap variabel terikat kepuasan pelanggan (Y). Berikut adalah hasilnya pada Tabel2. Persamaan regresi berganda sebagai berikut :

$\mathrm{Y}=1,919+0,511 \mathrm{X} 1-0,105 \mathrm{X} 2-0,-91 \mathrm{X} 3+$ $0,293 \mathrm{X} 4+0,211 \mathrm{X} 5+\mathrm{e}$

Pembahasan. Berdasarkan hasil analisis deskriptif diperoleh hasil bahwa responden mengatakan setuju bahwa pelayanan PT. PLN (Persero) dapat percaya dan data yang diberikan kepada pelanggan akurat. Hal ini menunjukkan tingkat variabel keandalan atau reability pada kualitas pelayanan PT. PLN (Persero) sudah baik. Sedangkan pernyataan hipotesis bahwa keandalan berpengaruh positif dan signifikan terhadap kepuasan pelanggan terbukti. Hal ini dapat ditunjukkan dengan nilai signifikansi (P Value) sebesar 0,00 yang berada diatas 0,05 serta nilai koefisien regresi sebesar 0,511. Dapat disimpulkan bahwa keandalan berpengaruh positif dan signifikan terhadap kepuasan pelanggan. Responden mengatakan sangat setuju bahwa pegawai PT. PLN (Persero) memiliki perilaku yang kurang dapat menimbulkan kepercayaan pelanggan, pegawai PT. PLN (Persero) kurang ramah dan kurang dapat menjawab pertanyaan dengan meyakinkan saat pelanggan menemui kesulitan, banyak waktu yang membuat pelanggan harus mencari jawaban yang ingin mereka dapatkan saat menemui kesulitan. Hal ini menunjukkan tingkat variabel jaminan atau assurance pada kualitas pelayanan PT. PLN (Persero) tidak baik. Sedangkan pernyataan hipotesis bahwa jaminan

Tabel 2

Rekapitulasi Hasil Analisa Regresi Berganda Coefficients'a

\begin{tabular}{|c|c|c|c|c|c|c|}
\hline \multirow{2}{*}{\multicolumn{2}{|c|}{ Model }} & \multicolumn{2}{|c|}{ Unstandardized Coefficients } & \multirow{2}{*}{$\frac{\text { Standardized Coefficients }}{\text { Beta }}$} & \multirow[t]{2}{*}{$\mathrm{T}$} & \multirow[t]{2}{*}{ Sig } \\
\hline & & $\mathrm{B}$ & Std. Error & & & \\
\hline \multirow[t]{6}{*}{1} & (Constant) & 1,919 & 1,551 & & 1,237 & ,219 \\
\hline & Tangible & ,211 &, 122 & ,238 & 1,733 & ,086 \\
\hline & Realibility & ,511 & ,099 & ,509 & 5,155 & ,000 \\
\hline & Responsivenes &,- 105 &, 100 &,- 124 & $-1,045$ & ,299 \\
\hline & Assurance &,- 091 &, 144 &,- 097 &,- 629 &, 531 \\
\hline & Emphaty & ,253 & , 110 & ,266 & 2,301 & ,024 \\
\hline
\end{tabular}

Sumber : Data hasil output SPSS 
berpengaruh positif dan signifikan terhadap kepuasan pelanggan tidak terbukti. Hal ini dapat ditunjukkan dengan nilai signifikansi ( $\mathrm{P}$ Value) sebesar 0,531 yang jauh diatas 0,05 serta nilai koefisien regresi sebesar-0,091. Dapat disimpulkan bahwa jaminan berpengaruh negatif tetapi tidak signifikan terhadap kepuasan pelanggan. Sebagian besar responden menyatakan kurang setuju bahwa PT. PLN (Persero) memiliki peralatan yang modern atau fasilitas fisik yang menarik, dan pegawai yang berpenampilan rapi. Hal ini menunjukkan tingkat variabel bukti fisik atau tangible pada kualitas pelayanan PT. PLN (Persero) kurang baik. Sedangkan pernyataan hipotesis bahwa bukti fisik berpengaruh positif dan signifikan terhadap kepuasan pelanggan tidak terbukti. Hal ini dapat ditunjukkan dengan nilai signifikansi (P Value) sebesar 0,086 yang jauh diatas 0,05 serta nilai koefisien regresi sebesar 0,211. Dapat disimpulkan bahwa bukti fisik berpengaruh positif tetapi tidak signifikan terhadap kepuasan pelanggan. Responden menyatakan setuju bahwa pegawai PT. PLN (Persero) memberikan perhatian secara individual kepada pelanggan, memiliki jam operasional yang sesuai dengan kebutuhan pelanggan, memberikan perhatian secara tulus, dan mampu memahami kebutuhan khusus pelanggan. Hal ini menunjukkan tingkat variabelempati pada kualitas pelayanan PT. PLN (Persero) sudah baik. Sementara untuk pernyataan hipotesis bahwa empati berpengaruh positif dan signifikan terhadap kepuasan pelanggan terbukti. Hal ini dapat ditunjukkan dengan nilai signifikansi (PValue) sebesar 0,024 yang lebih kecil dari 0,05 serta nilai koefisien regresi sebesar 0,253. Dapat disimpulkan bahwa semakin tinggi rasa empati yang diberikan PT. PLN (Persero) kepada pelanggan, maka akan semakin tinggi pula kepuasan pelanggannya. Sebagian besar responden menyatakan setuju bahwa pegawai PT. PLN (Persero) memberi tahu secara pasti kapan pelanggan akan dilayani, memberikan pelayanan yang cepat dan tepat, dan pegawai selalu berkeinginan untuk membantu pelanggan. Hal ini menunjukkan tingkat variabel daya tanggap atau responsiveness pada kualitas pelayanan PT. PLN (Persero) sudah baik. Sedangkan pernyataan hipotesis bahwa daya tanggap berpengaruh positif dan signifikan terhadap kepuasan pelanggan tidak terbukti. Hal ini dapat ditunjukkan dengan nilai signifikansi (PValue) sebesar 0,299 yang jauh diatas 0,05 serta nilai koefisien regresi sebesar $-0,105$. Dapat disimpulkan bahwa daya tanggap berpengaruh positif tetapi tidak signifikan terhadap kepuasan pelanggan. Responden menyatakan sangat setuju bahwa PT. PLN (Persero) memberikan pelayanan yang sesuai dengan harapan pelanggan. Hal ini menunjukkan tingkat kepuasan pelanggan pada PT. PLN (Persero) baik. Atas dasar perhitungan tersebut maka Ho ditolak atau berarti variable keandalan, jaminan, bukti fisik, empati, dan daya tanggap mempunyai pengaruh yang signifikan secara simultan (bersama-sama) terhadap variabel kepuasan pelanggan.

Berdasarkan hasil penelitian yang telah dilakukan dapat juga diketahui bahwa dari variabel kualitas pelayanan, variabel reability memiliki berpengaruh paling dominan terhadap kepuasan pelanggan, dimana variabel reability ini mempunyai pengaruh yang positif dan signifikan. Sedangkan faktor tangible, responsiveness dan assurance tidak mempunyai pengaruh terhadap kepuasan pelanggan.

\section{SIMPULAN}

Kesimpulan. Dari hasil penelitian yang dilakukan pada bab sebelumnya, dapat ditarik beberapa kesimpulan sebagai berikut :

1. Variabel tangibles tidak berpengaruh terhadap kepuasan pelanggan

2. Variabel realibility berpengaruh positif terhadap kepuasan pelanggan

3. Variabel responsiveness tidak berpengaruh terhadap kepuasan pelanggan

4. Variabel assurance tidak berpengaruh terhadap kepuasan pelanggan

5. Variabel emphaty berpengaruh positif terhadap kepuasan pelanggan.

\section{DAFTAR PUSTAKA}

Kotler, Philip. 2001 . Manajemen Pemasaran ; Analisis, Perencanaan, Implementasi, dan Kontrol . Jakarta: Prenhallindo.

Sianipar. 1999. MallManajemen Jasa . Yogyakarta : Andi. 
Moenir , 2000, Manajemen Pelayanan Publik, Jakarta ; Bina Aksara .

Ndraha, Taliziduhu, 2003 , Kybernology ( Ilmu Pemerintahan Baru ) Jilid 1 . Jakarta : Rineka Cipta.

Ratminto dan Atik Septi Winarsih, 2007, Manajemen Pelayanan Yogyakarta : Pustaka Belajar

Kotler, Philip dkk. 2000. Manajemen Pemasaran, Jakarta: Prenhallindo.

Kotler, Philip. 1997 . Manajemen Pemasaran . Edisi IX (terjemahan) . Jilid II . Jakarta : Erlangga Jakarta Cetakan XV.

Barata Atep Adya , 2003 , Dasar dasar Pelayanan Prima Jakarta : Gramedia Pustaka

Kaloh, J. 2003. Kepala Daerah (Pola Kegiatan, kekuasaan, dan Perilaku Kepala Daerah, dalam Pelaksanaan Otonomi Daerah). Jakarta : Gramedia

Pustaka Utama.Pelanggan Terhadap Kepuasan Pelanggan ( Studi pada Nasabah AsuransiPada PT. Prudential Life Assurance Semarang). Semarang : Skripsi.

Tjiptono, Fandy, 2003, Total Quality service. Yogyakarta: Andi Offset.

Zaenal Mukarom. Muhibudin Wijaya Laksana. 2015. Manajemen Pelayanan Publik. Bandung : Pustaka Setia.

Aryawan Tri Raharja , 2014 . Analisis Pengaruh Kualitas Pelayanan, Kualitas Produk, dan Nilai Yamit, Zulian , 2004, manajemen Kualitas Produk dan Jasa, Yogyakarta : Ekonesia. 